\title{
Changes in pectins of the Xylopodium of Ocimum nudicaule from dormancy to sprouting
}

\author{
Márcia Regina Braga ${ }^{*}$, Nicholas C. Carpita ${ }^{2}$, Sonia M. C. Dietrich ${ }^{1}$ and Rita de Cássia L. Figueiredo-Ribeiro ${ }^{1}$ \\ ${ }^{1}$ Seção de Fisiologia e Bioquímica de Plantas, Instituto de Botânica, C.P. 4005, 01061-970, São Paulo, SP,Brazil; ${ }^{2}$ Department of Plant \\ Pathology, Purdue University, USA; Corresponding author: bragamr@ig.com.br \\ Received: 22/03/2006, Accepted: 12/06/2006
}

The thickened underground organ of Ocimum nudicaule is a tuber-like structure (xylopodium) that is dormant in winter and sprouts at the beginning of the spring. Changes in content of cell wall polysaccharides were shown to occur from dormancy to sprouting. Pectic polysaccharides of $O$. nudicaule were analyzed in relation to composition, molecular mass, and linkage structure in these two phenological phases. The pectin content was $33 \%$ lower during sprouting when compared to dormancy. Changes were also observed in the molecular mass of the pectin fraction from dormancy to sprouting. Galacturonic acid was the predominant sugar, suggesting the presence of a homogalacturonan as the main pectic polysaccharide. A decrease in the acidic polysaccharides, homogalacturonans and rhamnogalacturonan I, equally accounted for the decrease in the pectin composition upon sprouting. These acidic carbohydrates were predominantly detected in the cell walls of the phellogen region of the xylopodium, suggesting catabolism of the cell walls of this tissue during bud flushing. These results suggest that variations in the content and in the molecular mass of pectins, in addition to changes in their composition and structure could be related to storage function as well as cell wall extension growth, both required for the sprouting of new buds in the xylopodium of O. nudicaule.

Key words: cell-wall polysaccharides, cerrado, Lamiaceae, underground reserve organs, xylopodium.

Variações nas pectinas de Ocimum nudicaule da dormência para a brotação. O órgão subterrâneo espessado de Ocimum nudicaule é um xilopódio, que permanece dormente durante o inverno e apresenta brotação no início da primavera. Alterações no conteúdo de polissacarídeos da parede celular ocorrem da dormência para a brotação nessa espécie. Neste trabalho, polissacarídeos pécticos de $O$. nudicaule foram analisados quanto à composição, tamanho molecular e estrutura nessas duas fases fenológicas. O conteúdo de pectinas foi 33 \% menor durante a brotação quando comparado à fase de dormência. Variações também foram observadas no tamanho molecular da fração péctica da dormência para a brotação. Ácido galacturônico foi o açúcar predominante, sugerindo a presença de um homogalaturonano como principal polissacarídeo péctico. Decréscimo dos polissacarídeos ácidos, homogalacturonanos e ramnogalacturonano I, também contribuíram para a diminuição observada com a brotação. Esses polissacarídeos ácidos foram detectados predominantemente no felogênio, sugerindo catabolismo das paredes celulares desse tecido durante a brotação. Os resultados obtidos sugerem que variações no conteúdo e tamanho molecular das pectinas, em adição a mudanças na sua composição e estrutura, podem estar relacionadas à função de reserva, assim como à expansão celular, ambos processos necessários para a brotação do xilopódio de $O$. nudicaule.

Palavras-chave: polissacarídeos de parede celular, cerrado, Lamiaceae, órgãos subterrâneos de reserva, xilopódio.

\section{INTRODUCTION}

Plants are continually exposed to a great variety of environmental stresses that influence their growth and development. Winter drought is one of the most important stress conditions imposed to herbaceous plant species growing in cerrado (savanna-like vegetation) areas in
Brazil. The phenological behavior of the cerrado vegetation is related to environmental stimuli, and appears to represent a series of adaptive strategies to overcome thermal, nutritional, and osmotic stresses (Mantovani and Martins, 1988). Overwinter survival of the herbaceous component of the cerrado is dependent on carbohydrates stored in large 
amounts in thickened underground reserve organs before the abscission of the aerial parts (Carvalho and Dietrich, 1993; Vieira and Figueiredo-Ribeiro, 1993).

Ocimum nudicaule Benth. var. anisifolia is a small rosette-herb growing spontaneously in cerrado vegetation in Southern Brazil (Figueiredo-Ribeiro et al., 1983). The thickened underground organ of this species is a tuber-like structure (xylopodium), which is dormant in winter and sprouts at the beginning of the spring (figure 1). Since it arises from the hypocotyl and the base of the primary root, the xylopodium has mixed features of stem and root (Figueiredo, 1972; Milanez and Moraes-Dallaqua, 2003). It also has been described as a water storage organ of herbaceous species from the cerrado (Rizzini and Heringer, 1961).

Starch is not detected in the xylopodium of $O$. nudicaule, and soluble sugars and cell-wall storage carbohydrates constitute the main source of energy for bud growth (Figueiredo-Ribeiro and Dietrich, 1981; Figueiredo-Ribeiro et al., 1992). Changes in both content and composition of non-cellulosic polysaccharides, such as arabinoxylans, were shown to occur from dormancy to sprouting. Pectins also decrease during sprouting (Figueiredo-Ribeiro et al., 1992), but changes in their composition during dormant and sprouting phases were not investigated.

Pectin is the most abundant class of macromolecules within the cell wall matrix. In addition, it is abundant in the middle lamellae, between primary cell walls where it functions in regulating intercellular adhesion. Pectin is one of the major components of primary cell walls and it is generally thought to account for about one third of all primary cell wall molecules (Willats et al., 2001). Several findings suggest that the cell wall composition and architecture, mainly related to the alterations in cross-linked glycans and pectins, play a central role in the responses of plants to various environmental signals (Gunawardena et al., 2001; Nakamura et al., 2003). Considering the contribution of pectins to the water relations in storage organs and their influence to the mechanical properties of the cell walls, composition and structure of pectic polysaccharides of $O$. nudicaule were analyzed in this work during dormancy and sprouting.

\section{MATERIAL AND METHODS}

Xylopodia were harvested from plants of Ocimum nudicaule Benth. var. anisifolia Giul. (Lamiaceae) cultivated at the Instituto de Botânica de São Paulo, by means of vegetative propagation of plants originally brought from the state of Mato Grosso do Sul (Brazil). A voucher sample is deposited in the "Eneida K. Fidalgo" Herbarium (Instituto de Botânica, SP, Brazil) under number SP 79700. Ten xylopodia were collected representative of the dormancy and sprouting stages.

Fragments collected from xylopodia of $O$. nudicaule during the sprouting phase were rinsed in distilled water and fixed in Bouin solution for $24 \mathrm{~h}$ (Pearse, 1968). Subsequent dehydration and paraffin embedding procedures were performed according to Sass (1951). Sections of 12 to $20 \mu \mathrm{m}$ were cut using a microtome, mounted on glass microscope slides, and stained with Alcian Blue (AB) (Pearse 1968) and /or periodic acid plus Schiff reagent (PAS) (Alves, 1976). Acidic material in the cell walls was visualized under light microscopy after the development of blue/purple stain at $\mathrm{pH} 2.5$.

Cell walls were prepared as alcohol-insoluble residue (AIR) as described by Figueiredo-Ribeiro et al. (1992). The AIR was ground in a 40-mesh mill and lipids and pigments were removed using benzene:ethanol $(2: 1, \mathrm{v} / \mathrm{v})$ for $72 \mathrm{~h}$ under reflux. The residue was dried at $60{ }^{\circ} \mathrm{C}$ for $48 \mathrm{~h}$, yielding the cell wall dry mass.

Pectins were extracted twice with hot water at $80^{\circ} \mathrm{C}$ for 2 h. The insoluble material was then extracted twice with 0.25 $\%$ ammonium oxalate $\left(\mathrm{pH} 7.0\right.$ ) at $70^{\circ} \mathrm{C}$ under $\mathrm{N}_{2}$ for $1 \mathrm{~h}$ each. The supernatants were combined, precipitated with three volumes of absolute ethanol and the pellet was recovered by centrifugation, freeze-dried, and weighed. The dried pectins were re-solubilized in $0.5 \%$ ammonium oxalate $(\mathrm{pH} 7.0)$ at $30^{\circ} \mathrm{C}$ and dialyzed against deionized water for $48 \mathrm{~h}$. The supernatant was recovered by centrifugation at $2,500 \mathrm{~g}_{n}$ and evaluated for uronic acid by the $m$-hydroxybiphenyl method (Filisetti-Cozzi and Carpita, 1991) and for total sugar content by phenol-sulfuric assay (Dubois et al., 1956), using galacturonic acid and glucose, respectively, as standards.

Aliquots of pectins were freeze-dried, dissolved in $150 \mathrm{mM}$ McIlvaine buffer ( $\mathrm{pH}$ 5.2), and loaded onto a Sepharose 4B Pharmacia column $(1.5 \mathrm{~cm}$ i.d. x $54 \mathrm{~cm}$, Bio Rad) equilibrated in the same buffer. Fractions $(2 \mathrm{~mL})$ were eluted at a flow rate of $18 \mathrm{~mL} \cdot \mathrm{h}^{-1}$ and assayed for uronic acids and sugar contents. Linear dextrans $\left(M_{r} 2,000,156,76\right.$ and $10 \mathrm{kDa}$ ) were used for calibration.

Aliquots of the pectin fraction were hydrolyzed with 2 $\mathrm{M} \mathrm{TFA}$ at $120^{\circ} \mathrm{C}$ for $1 \mathrm{~h}$. The acid was subsequently removed under vacuum. Neutral sugars from the fractions of the Sepharose 4B column were analyzed by high performance anion exchange chromatography (HPAEC/PAD) in a Dionex DX-500 system. After deionization through cation (Dowex 
$-50 \mathrm{~W}, \mathrm{Na}^{+}$form) and anion (Dowex- $1, \mathrm{Cl}^{-}$form) resins, the neutral monosaccharides were analyzed on a Carbo-Pac PA-10 column using isocratic $20 \mathrm{mM} \mathrm{NaOH}$ as eluent (1 $\left.\mathrm{mL} \cdot \mathrm{min}^{-1}\right)$. The elution time of each sugar was compared to those of monosaccharide standards.

Uronic acids in the pectin samples were activated with 1-cyclohexyl-3-(2-morpholinyl-4-ethyl) carbodiimide (methyl-p-toluene sulfonate) (CMC, Aldrich Chemicals) and reduced with $\mathrm{NaBD}_{4}$ to their respective 6,6-dideuterio galactose residues (Carpita and McCann, 1996). Uronosylreduced wall material (1-2 mg) was hydrolyzed in $1 \mathrm{~mL}$ of $2 \mathrm{M}$ trifluoroacetic acid (TFA) at $120^{\circ} \mathrm{C}$ for $90 \mathrm{~min}$, and the supernatant was then evaporated in a stream of nitrogen. The sugars were reduced with $\mathrm{NaBH}_{4}$ and alditol acetates were prepared as described previously (Gibeaut and Carpita, 1991). Derivatives were separated by gas-liquid chromatography (GLC) on a $0.25-\mathrm{mm} \times 30-\mathrm{m}$ column of SP-2330 (Supelco, Bellefonte, PA). Temperature was held at $80^{\circ} \mathrm{C}$ during injection, then ramped quickly to $170^{\circ} \mathrm{C}$ at $25^{\circ} \mathrm{C}$ $\mathrm{min}^{-1}$, and then to $240^{\circ} \mathrm{C}$ at $5^{\circ} \mathrm{C} \cdot \mathrm{min}^{-1}$ with a 10 -min hold at the upper temperature. Helium flow was $1 \mathrm{~mL} \cdot \mathrm{min}^{-1}$ with splitless injection. The electron impact mass spectrometry (EIMS) was performed with a Hewlett-Packard MSD at $70 \mathrm{eV}$ and a source temperature of $250^{\circ} \mathrm{C}$. The proportion of 6,6-dideuteriogalactosyl was calculated using pairs of diagnostic fragments $\mathrm{m} / \mathrm{z}$ 187/189, 217/219 and 289/291 according to the equation described in Kim and Carpita (1992) that accounts for spillover of ${ }^{13} \mathrm{C}$.

For linkage analysis polysaccharides were per-Omethylated with $\mathrm{Li}^{+}$methylsulfinylmethanide, prepared by addition of n-butyllithium to dry dimethyl sulfoxide (DMSO), and methyl iodide according to Gibeaut and Carpita (1991). The per-O-methylated polymers were recovered after addition of water to the mixture and partitioning into chloroform. The chloroform extracts were washed five times with a three-fold excess of water each, and the chloroform was evaporated in a stream of nitrogen gas. The methylated polymers were purified by chloroform partitioning and hydrolyzed in $2 \mathrm{M}$ TFA for $90 \mathrm{~min}$ at $120^{\circ} \mathrm{C}$. The TFA was evaporated in a stream of nitrogen gas, and the sugars were then reduced with $\mathrm{NaBD}_{4}$ and acetylated. The partly methylated alditol acetates were separated on the column as the alditol acetates, after a hold at $80^{\circ} \mathrm{C}$ for $1 \mathrm{~min}$ during injection and rapid ramping; the derivatives were separated in a temperature program of $160^{\circ} \mathrm{C}$ to $210^{\circ} \mathrm{C}$ at $2^{\circ} \mathrm{C}$ per min, then to $240^{\circ} \mathrm{C}$ at $5^{\circ} \mathrm{C}$ per min, with a hold of 5 min at the upper temperature. All derivative structures were confirmed by electron-impact mass spectrometry (Carpita and Shea, 1989).

\section{RESULTS}

The histochemical analysis of the transverse sections of xylopodium of $O$. nudicaule during sprouting showed that cell wall polysaccharides are spatially distributed in the organ (figure 2). Neutral carbohydrates detected by PAS were shown to predominate in the cell walls of the peripheral tissues, including the phellem (figure 2A). Alcian Blue dye stained more intensely cell walls of the phellogen region and phloem, indicating that acidic polysaccharides are preferentially located in these tissues (figure $2 \mathrm{~B}$ ). The purple staining observed when sections were treated with both dyes (figure 2C) confirmed the predominance of acidic polysaccharides in this region of intense metabolic activity.

The pectin content of the xylopodia of $O$. nudicaule decreased by $c a .33 \%$ ( 8.6 to $5.7 \%$ of the cell wall dry mass) during sprouting when compared to the dormancy phase, as previously reported by Figueiredo-Ribeiro et al. (1992). After ethanol precipitation, only small amounts of total

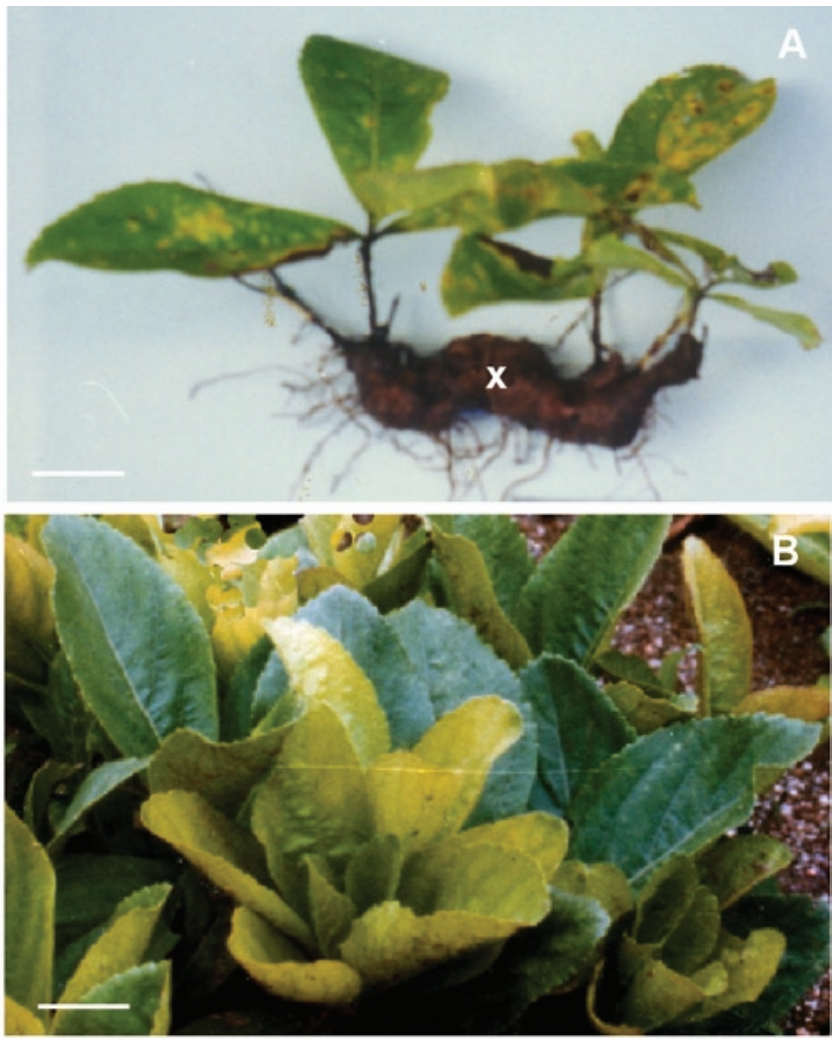

Figure 1. General aspects of plants of Ocimum nudicaule at the beginning of dormancy (A) and at the sprouting (B) phases. $\mathrm{X}=$ xylopodium. Bars $=4 \mathrm{~cm}(\mathrm{~A})$ and $3 \mathrm{~cm}(\mathrm{~B})$. 
carbohydrate could be re-solubilized from the pectin fraction, accounting for $15.7 \%$ and 11.6 of the dry mass of these fractions for dormancy and sprouting, respectively. Uronic acids, measured by colorimetric assay, represented more than $45 \%$ of the pectin fraction for both phenological phases.

Changes were also observed in the molecular mass distribution of pectic polysaccharides between dormancy and sprouting (figures $3 \mathrm{~A}$ and $\mathrm{B}$ ). In both phases, uronic acids co-eluted with the largest bulk of neutral sugars but a considerable reduction in the polydispersion of the neutral polysaccharides was observed during sprouting (figure 3B). In this phase, weight-average molecular mass of acidic polysaccharides exhibited an apparent increase probably as a result of degradation of polymers with lower molecular weight. HPAEC/PAD analysis of neutral sugars revealed that the composition of fractions with different molecular masses was similar, with the predominance of galactose, glucose, and arabinose (data not shown).

Galacturonic acid was the predominant sugar found in the pectin fractions from both phenological phases, its proportion tending to decrease during sprouting (table 1). Consistent with this result, the high proportion of 4linked galacturonic acid residues detected by glycosyl linkage composition analysis indicated the presence of homogalacturonans as the major acidic polysaccharide in the pectins of $O$. nudicaule (table 2). Two- and 2,4linked rhamnosyl residues commonly associated with rhamnogalacturoran-I (RG-I) were also detected. Although present in lower proportion, when compared to the homogalacturonans, RG-I also decreased during sprouting (table 2).

The amounts of galactosyl and arabinosyl residues and the presence of 3,6-linked galactosyl residues suggest that pectins contain type-II arabinogalactans as the main neutral component of this cell wall fraction, its proportion being slightly higher during sprouting. Based on the proportion of 3,4-linked galactosyl residues, type-I arabinogalactan seemed to be present as a minor component of the cell wall pectins from the xylopodia (table 2).

Glucose was also present in appreciable proportion in $O$. nudicaule pectin fractions from both phenological phases (table 1). Contamination of the pectin fraction with starch was discarded since this reserve polysaccharide is not detectable in the xylopodium (Figueiredo-Ribeiro and Dietrich, 1981). Glycosyl linkages expected from xyloglucan of type-I walls (2-xylosyl, 4,6-glucosyl, 2-galactosyl and $t$-fucosyl) were

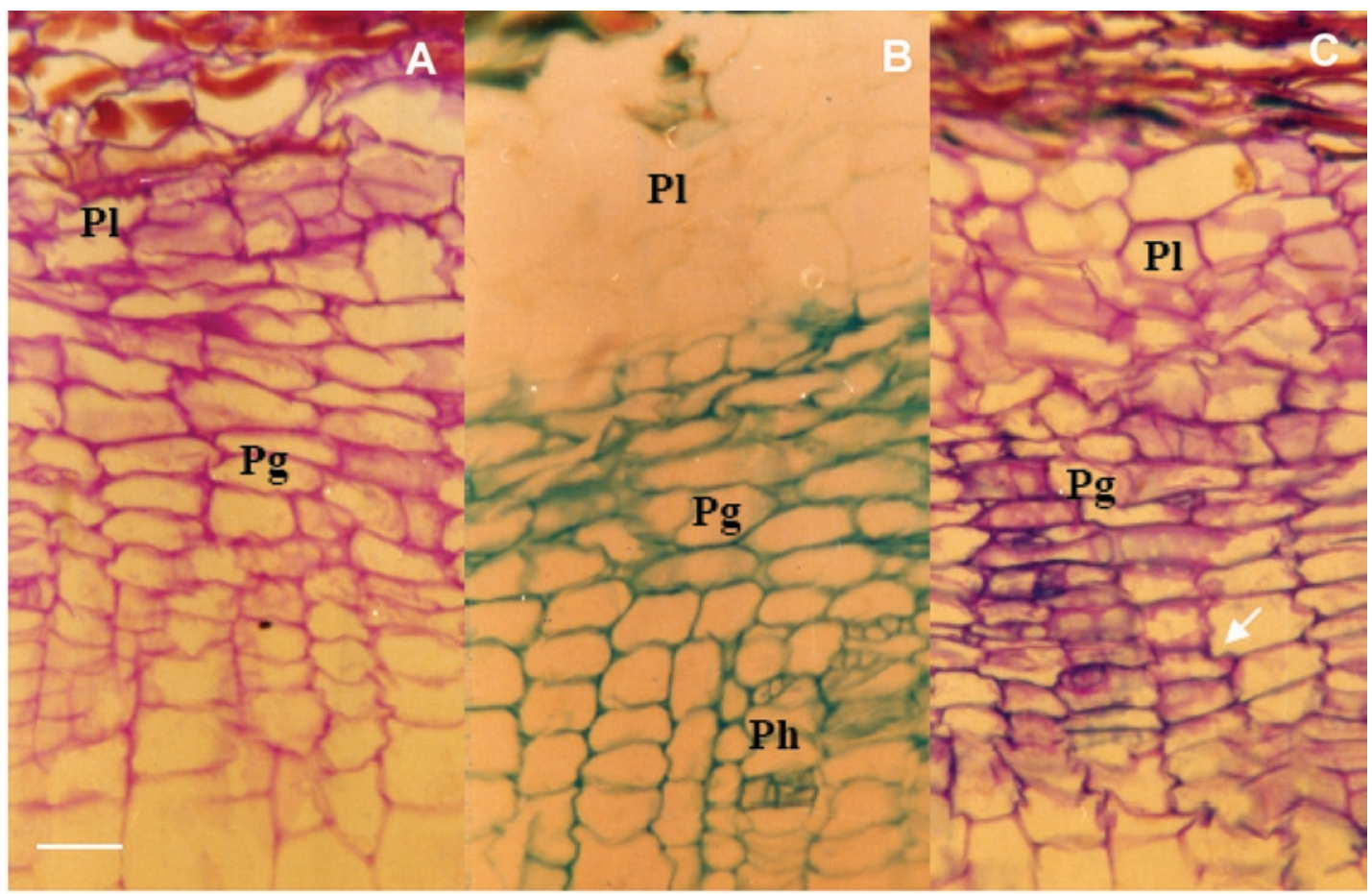

Figure 2. Detection of neutral and acidic carbohydrates in the cell walls of transversal sections of the xylopodium of Ocimum nudicaule during sprouting. Staining with PAS (A), Alcian Blue (B), and PAS + Alcian Blue (C). The arrow indicates cell wall stained in purple due to the concomitant presence of neutral and acidic carbohydrates. $\mathrm{Pl}=$ phellem, $\mathrm{Pg}=$ phellogen, $\mathrm{Ph}$ $=$ phloem. Bar $=40 \mu \mathrm{m}$. 
detected in this fraction, indicating that the glucose residues are from this cross-linking glucan (table 2).

From methylation analysis, 4-linked xylosyl residues were also detected in the pectins (table 2), indicating the presence of a xylan in this cell wall fraction. This polymer appears to be branched at every eight residues solely at the O-2 position, as indicated by the relative amount of 2,4linked xylosyl residues. The presence of this substituted xylan accounted in part for the $t$-Ara present in this fraction. Four-linked mannosyl, 4-linked glucosyl and 4,6-linked galactosyl residues as shown by the glycosyl-linkage analysis, suggest the presence of minute amounts of a glucomannan as part of the pectin fraction (table 2).

\section{DISCUSSION}

Biochemical modifications of cell wall polysaccharides, such as adjustments in the molecular size and quantities of wall polysaccharides, have been considered to be involved in the responses of plants to various environmental stimuli (Soga et al., 1999a,b; Hoson et al., 2002; Nakamura et al.,
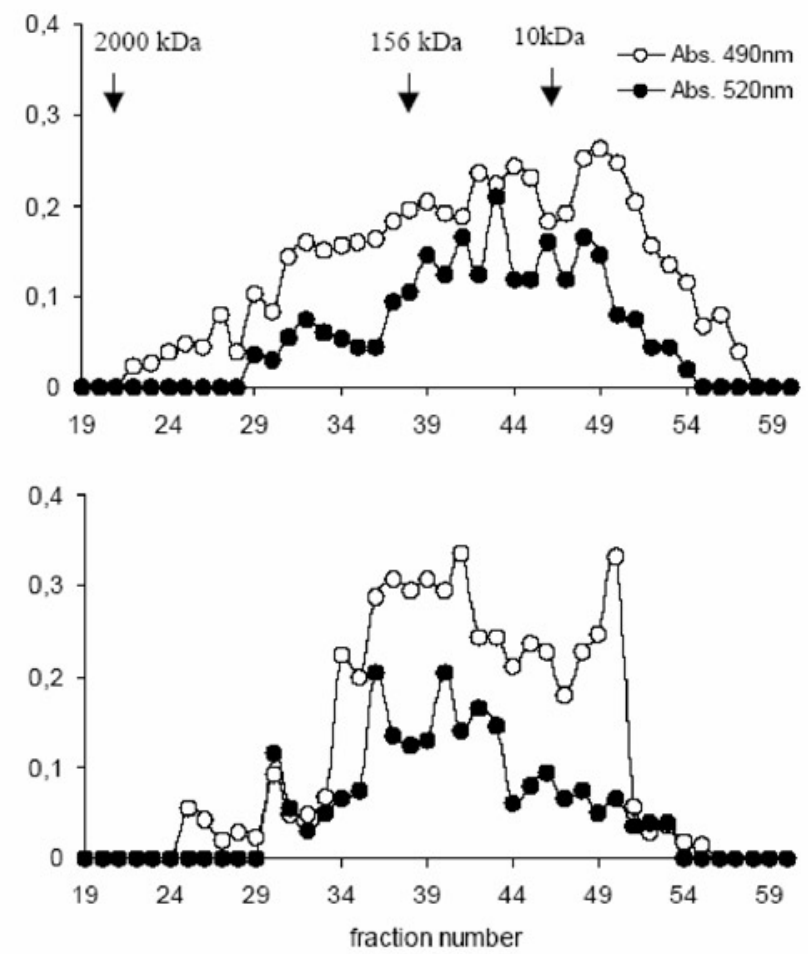

Figure 3. Sepharose 4B gel-permeation chromatography of pectins from Ocimum nudicaule xylopodia in dormancy (A) and sprouting (B) phases. Fractions $(3 \mathrm{~mL})$ were assayed colorimetrically for sugar content $(\lambda 490 \mathrm{~nm})$ by the phenolsulfuric method and for uronic acids $(\lambda 520 \mathrm{~nm})$ by the $m$ hydroxybiphenyl procedure.
Table 1. Comparison of monosaccharide distributions of pectins from dormant and sprouting xylopodia of Ocimum nudicaule.

\begin{tabular}{lll}
\hline Monosaccharide* & Dormant & Sprouting \\
\hline & & mole $\%$ \\
Rhamnose & $6.7 \pm 0.3$ & $5.7 \pm 1.0$ \\
Fucose & $1.2 \pm 0.5$ & $0.9 \pm 0.3$ \\
Arabinose & $9.1 \pm 0.6$ & $9.1 \pm 1.6$ \\
Xylose & $6.7 \pm 0.4$ & $6.6 \pm 0.7$ \\
Mannose & $2.6 \pm 0.3$ & $2.6 \pm 0.3$ \\
Galactose & $19.7 \pm 0.6$ & $21.2 \pm 1.7$ \\
Glucose & $11.0 \pm 0.9$ & $13.0 \pm 4.8$ \\
Galacturonic Acid & $43.1 \pm 1.7$ & $40.9 \pm 3.2$ \\
\hline \hline
\end{tabular}

* Uronic acids were reduced with sodium borodeuteride to their corresponding 6,6-dideuterogalactose residues according to Carpita and McCann (1996), and calculations of proportions of $\mathrm{Gal}$ and GalA residues were determined as described by Kim and Carpita (1992). Values are mean \pm S.D. of four samples.

Table 2. Linkage analysis of pectins extracted from dormant and sprouting xylopodia of Ocimum nudicaule.

\begin{tabular}{|c|c|c|}
\hline Linkage & Dormant & Sprouting \\
\hline & \multicolumn{2}{|c|}{ mole $\%$} \\
\hline$t$-Fuc $p$ & 1.2 & 0.9 \\
\hline$t$-Rhap & 1.2 & 0.8 \\
\hline 2-Rhap & 2.9 & 2.5 \\
\hline 2,4-Rhap & 2.6 & 2.4 \\
\hline$t$-Ara $f$ & 2.1 & 2.3 \\
\hline$t$-Arap & 0.7 & 0.6 \\
\hline 2-Araf & 0.1 & 0.2 \\
\hline 3-Araf & 1.2 & 0.9 \\
\hline 5-Araf & 3.4 & 3.5 \\
\hline 2,5-Ara $f$ & 0.8 & 0.9 \\
\hline 3,5-Araf & 0.8 & 0.8 \\
\hline$t-\mathrm{Xyl} p$ & 1.8 & 1.0 \\
\hline 2-Xylp & $\operatorname{tr}$ & $\operatorname{tr}$ \\
\hline 4-Xylp & 4.1 & 4.5 \\
\hline $2,4-\mathrm{Xyl} p$ & 0.5 & 0.6 \\
\hline $3,4-\mathrm{Xyl} p$ & 0.3 & 0.5 \\
\hline$t$-Man $p$ & 0.5 & 0.5 \\
\hline 4-Man $p$ & 1.7 & 1.8 \\
\hline 4,6-Man $p$ & 0.5 & 0.3 \\
\hline$t$-Galp & 3.0 & 3.5 \\
\hline 2-Galp & 1.0 & 1.0 \\
\hline 3-Galp & 1.4 & 1.5 \\
\hline 4-Galp & 1.4 & 1.3 \\
\hline 6-Galp & 4.6 & 5.3 \\
\hline $3,4-\mathrm{Gal} p$ & 0.8 & 0.8 \\
\hline 3,6-Galp & 5.7 & 6.4 \\
\hline 4,6-Gal $p$ & 1.7 & 1.5 \\
\hline$t$-Glc $p$ & 2.5 & 2.2 \\
\hline 4-Glcp & 2.9 & 7.4 \\
\hline $4,6-\mathrm{Glc} p$ & 2.8 & 1.3 \\
\hline$t$-GlcA & 2.3 & 2.1 \\
\hline$t$-GalA & 2.7 & 2.2 \\
\hline 4-GalA & 33.3 & 31.9 \\
\hline 3,4-GalA & 7.1 & 6.8 \\
\hline
\end{tabular}


2003). In the xylopodium of $O$. nudicaule, changes in the cell wall composition and cross-linking glycan content were observed at the beginning of spring (September), when the sprouting of new buds takes place (Figueiredo-Ribeiro et al., 1992).

The results of the present study showed that changes in the yield and composition of pectins also occurred in cell walls of the xylopodium during sprouting. A decrease in the acidic polysaccharides, homogalacturonans and rhamnogalacturonan I, was the most striking change in pectin composition following sprouting (tables 1 and 2). These acidic carbohydrates were concentrated in the cell walls of the phellogen region, indicating that an intense metabolic activity is taking place in the cell walls of this tissue during bud flushing (figure 2). According to Sabba and Lulai (2005), deposition of pectins is likely a biochemical process involved in the thickening and strengthening of phellogen walls observed during maturation of the periderm in potato tuber. This is in agreement with the increased amount of the pectin fraction observed during dormancy of $O$. nudicaule xylopodium.

Many herbaceous plants from the cerrado, such as Ocimum nudicaule, display a characteristic annual growth cycle with intensive sprouting and vegetative growth in spring (September-December) and summer (DecemberMarch), leaf fall at the end of autumn (March-June), and dormancy during the dry winter season (June-September). Dormant underground organs of these plants store large amounts of carbohydrates, which are mobilized in the next growth period (Figueiredo-Ribeiro and Dietrich, 1981; Carvalho and Dietrich, 1993; 1996). Xylans, although reported as being a minor component of cell walls from dicots and non-gramineous monocots (Carpita and Gibeaut, 1993), were shown to predominate in underground organ of O. nudicaule (Figueiredo-Ribeiro et al., 1992). The absence of starch and the depletion of the xylan content associated to an increase in the cell wall degrading enzymes (FigueiredoRibeiro and Dietrich, 1981; Figueiredo-Ribeiro et al., 1983) during sprouting pointed to the role of this polysaccharide as a reserve carbohydrate in $O$. nudicaule. According to these authors, the decline in the non-cellulosic polymer content is related to an increased energy demand by the growing buds.

During winter, characterized by a decline in rainfall and reduction of temperature, plants from the cerrado are exposed to temperature and water stresses (Mantovani and Martins, 1988). Thickened underground structures such as the xylopodium of $O$. nudicaule have been considered as water storage organs in herbaceous species from the cerrado (Rizzini and Heringer, 1961). Pectins are involved in the porosity properties and in the maintenance of the wall hydration status through their capacity to form gels (Willats et al., 2001). Therefore, the acidic domain of the pectic network, whose content is higher in the xylopodium of $O$. nudicaule during dormancy when compared to sprouting, could be implicated in the maintenance of the hydration state of the organ in the dry season.

Changes in pectin content and composition have impact on the cell wall properties and cell development (Willats et al., 2001). Several findings have related changes in the extensibility of the cell walls due to an increase in the molecular size of the wall matrix polysaccharides in response to environmental signals (Soga et al., 1999a; b; Hoson et al., 2002; Nakamura et al., 2003). Therefore, the increase in the average molecular weight of acidic polysaccharides from pectins of $O$. nudicaule (figure 3 ) could be related to cell wall loosening required for the growth of new buds.

Data presented in this paper provide information about the dynamics of pectins in underground organs of $O$. nudicaule associated with phenological changes during the life cycle of the plant. Underground organs are not homogeneous structures and their pectic composition has been shown to be spatial and developmentally regulated (Bush et al., 2001, Bush and McCann, 1999). Variations in the content and in the molecular mass of pectins, in addition to changes in their composition can be related to storage function and cell wall loosening, both required for the sprouting of new buds in the xylopodium of $O$. nudicaule. Therefore, specific changes in the pectin domain in the xylopodium could augment the contribution of these polymers to the mechanical properties of the cell walls during the plant growth cycle.

Acknowledgments: Thanks are due to $\mathrm{CNPq}$ for the research fellow grants to M.R. Braga, S.M.C. Dietrich, and R.C.L. Figueiredo-Ribeiro. We also thank Dr. M.A.S. Tiné for helping with the figures. This work was supported by FAPESP (BIOTASP 98/05124-8).

\section{REFERENCES}

Alves CER (1976) Morfologia e histoquímica comparadas da epiderme de Oligochaeta terrestre (Annelida). São Paulo, University of São Paulo, $\mathrm{PhD}$ thesis.

Bush MS, McCann MC (1999) Pectic epitopes are differentially distributed in the cell walls of potato (Solanum tuberosum) tubers. Physiol. Plant. 107:201-213. 
Bush MS, Marry M, Huxham IM, Jarvis MC, McCann MC (2001) Developmental regulation of pectic epitopes during potato tuberisation. Planta 213:869-880.

Carpita NC, Gibeaut DM (1993) Structural models of primary cell walls in flowering plants: consistency of molecular structure with the physical properties of the walls during growth. Plant J. 3:1-10.

Carpita NC, McCann MC (1996) Some new methods to study plant polyuronic acids and their esters. In: Townsend R, Hotchkiss A (eds), Progress in Glycobiology, pp. 595-611. Marcell Dekker, New York, USA.

Carpita N, Shea EM (1989) Linkage structure by gas chromatography-mass spectrometry of partially-methylated alditol acetates. In: Biermann CJ, McGinnis GD (eds), Analysis of Carbohydrates by GLC and MS. pp. 155-216. CRC Press, Boca Raton, USA.

Carvalho MAM, Dietrich SMC (1993) Variation in fructan content in the underground organs of Vernonia herbacea (Vell.) Rusby at different phenological phases. New Phytol. 123:735-740.

Carvalho CGS, Dietrich SMC (1996) Carbohydrates in tuberous roots of Cochlospermum regium (Mart. and Schr.) Pilger at different stages of development. Rev. Bras. Bot. 19:127-131.

Dubois M, Gilles A, Hamilton JK, Rebers PA, Smith F (1956) Colorimetric method for determination of sugars and related substances. Anal. Chem. 28:350-355.

Figueiredo-Ribeiro RCL (1972) The anatomy of vegetative organs of Ocimum nudicaule Benth. (Labiatae). An. Acad. Brasil. Ciên. 44:549-570.

Figueiredo-Ribeiro RCL, Dietrich, SMC (1981) Seasonal variations in the reserve compounds and metabolism of the xylopodium of Ocimum nudicaule Benth. var. anisifolia Giul. (Labiatae). Rev. Bras. Bot. 4:73-82.

Figueiredo-Ribeiro RCL, Dietrich SMC, Macha N (1983) Seasonal changes and histochemical location of phosphatases and peroxidase in the xylopodium of Ocimum nudicaule var. anisifolia. Hoehnea 10:1-8.

Figueiredo-Ribeiro RCL, Isejima EM, Dietrich SMC, Corrêa JBC (1992) Hemicellulosic polysaccharides from the xylopodium of Ocimum nudicaule: changes in composition in dormancy and sprouting. Ann. Bot. 70:405-408.

Filisetti-Cozzi TMC, Carpita NC (1991) Measurement of uronic acids without interference from neutral sugars. Anal. Biochem. 197:157-162.

Gibeaut DM, Carpita NC (1991) Tracing cell wall biogenesis in intact cells and plants: selective turnover and alteration of soluble and cell wall polysaccharides in grasses. Plant Physiol. 97:551-561.
Gunawardena AHLAN, Pearce DME, Jackson MB, Hawes CR, Evans DE (2001) Rapid changes in cell wall pectic polysaccharides are closely associated with early stages of aerenchyma formation, a spatially localized form of programmed cell death in roots of maize (Zea mays L.) promoted by ethylene. Plant Cell Environ. 24:1369-1375.

Hoson T, Soga K, Mori R, Saiki M, Nakamura Y, Wakabayashi KW, Kamisaka S (2002) Stimulation of elongation growth and cell wall loosening in rice coleoptiles under microgravity conditions in space. Plant Cell Physiol. 43: 1067-1071.

Kim J-B, Carpita NC (1992) Changes in esterification of the uronic acid groups of cell wall polysaccharides during elongation of maize coleoptiles. Plant Physiol. 98:646-653.

Mantovani W, Martins FR (1988) Phenological variations in the cerrado species from the biological reserve at Mogi-Guaçu, State of São Paulo, Brazil. Rev. Bras. Bot. 11:101-112.

Milanez CRD, Moraes-Dallaqua MA (2003) Ontogeny of the subterranean system of Pachyrhizus ahipa (Wedd.) Parodi (Fabaceae). Rev. Bras. Bot. 26:415 - 427.

Nakamura Y, Wakabayashi KW, Hoson T (2003) Temperature modulates the cell wall mechanical properties of rice coleoptiles by altering the molecular mass of hemicellulosic polysaccharides. Physiol. Plant. 118:597-604.

Pearse AGE (1968) Histochemistry. Theoretical and Applied. Vol I, Churchill, London.

Rizzini CT, Heringer EP (1961) Underground organs of plants from some southern Brazilian savannas, with special reference to the xylopodium. Phyton 17:105-124.

Sabba R, Lulai EC (2005) Immunocytological analysis of potato tuber periderm and changes in pectin and extensin epitopes associated with periderm maturation. J. Amer. Soc. Hort. Sci. 130:936-942.

Sass JE (1951) Botanical microtechnique. The Iowa State College Press, Iowa.

Soga K, Harada K, Wakabayashi KW, Hoson T, Kamisaka S (1999a) Increased molecular mass of hemicellulosic polysaccharides is involved in growth inhibition of maize coleoptiles and mesocotyls under hypergravity conditions. J. Plant Res. 112:273-278.

Soga K, Wakabayashi KW, Hoson T, Kamisaka S (1999b) Hypergravity increases the molecular mass of xyloglucans by decreasing xyloglucan-degrading activity in azuki bean epicotyls. Plant Cell Physiol. 40:581-585.

Vieira CCJ, Figueiredo-Ribeiro RCL (1993) Fructose-containing carbohydrates in the tuberous root of Gomphrena macrocephala St.-Hil. (Amaranthaceae) at different phenological phases. Plant Cell Environ.16:919-928.

Willats WGT, McCartney L, Mackie W, Knox JP (2001) Pectin: cell biology and prospects for functional analysis. Plant Mol. Biol. 47:9-27 